\title{
Learning and Teaching Online During Covid-19: Experiences of Student Teachers in an Early Childhood Education Practicum
}

\author{
Jinyoung $\operatorname{Kim}^{1}[$
}

Published online: 30 July 2020

(c) Springer Nature B.V. 2020

\begin{abstract}
Online learning is an educational process which takes place over the Internet as a form of distance education. Distance education became ubiquitous as a result of the COVID-19 pandemic during 2020. Because of these circumstances, online teaching and learning had an indispensable role in early childhood education programs, even though debates continue on whether or not it is beneficial for young children to be exposed extensively to Information and Communication Technology (ICT). This descriptive study demonstrates how a preservice teacher education course in early childhood education was redesigned to provide student teachers with opportunities to learn and teach online. It reports experiences and reflections from a practicum course offered in the Spring Semester of 2020, in the USA. It describes three phases of the online student teachers' experiences-Preparation, Implementation, and Reflection. Tasks accomplished in each phase are reported. Online teaching experiences provided these preservice teachers with opportunities to interact with children, as well as to encourage reflection on how best to promote young children's development and learning with online communication tools.
\end{abstract}

Keywords Distance education · Online learning · Early childhood education · Preservice teacher education $\cdot$ Student teachers

\section{Résumé}

L'apprentissage en ligne est un processus éducatif qui se déroule sur l'internet comme forme d'enseignement à distance. L'enseignement à distance est devenu omniprésent suite à la pandémie de COVID-19 en 2020. En raison de ces circonstances, l'enseignement et l'apprentissage en ligne ont joué un rôle indispensable dans les programmes d'éducation de la petite enfance, même si les débats se poursuivent sur les effets bénéfiques ou non d'une exposition intense des jeunes enfants aux

Jinyoung Kim

Jinyoung.Kim@csi.cuny.edu

1 School of Education, College of Staten Island, The City University of New York, 2800 Victory Boulevard, Staten Island, NY 10314, USA 
technologies de l'information et des communications (TIC). Cette étude descriptive montre comment un cours en éducation de la petite enfance en formation initiale à l'enseignement a donné à des enseignants-étudiants des occasions d'apprendre et d'enseigner en ligne. Elle rend compte des expériences et des réflexions d'un enseignant universitaire dans le cadre d'un cours pratique offert aux États-Unis pendant la session du printemps de 2020. Elle décrit trois phases de l'expérience en ligne des enseignants-étudiants : préparation, application et réflexion. Les candidats enseignants rendent compte des tâches réalisées durant chaque phase en lien avec leur apprentissage et leur enseignement. Les expériences d'enseignement en ligne ont apporté à ces enseignants en formation initiale des occasions d'interagir en ligne avec les enfants et ont aussi favorisé une réflexion sur la meilleure façon de promouvoir le développement et l'apprentissage des jeunes enfants avec des outils de communication en ligne.

\section{Resumen}

La enseñanza en línea es un proceso educativo que se lleva a cabo por Internet como forma de educación a distancia. La educación a distancia se generalizó como resultado de la pandemia COVID-19 en el 2020. Como resultado, la educación en línea asumió un papel indispensable en programas de educación preescolar, a pesar de que sus beneficios continúan siendo materia de discusión y no existe consenso en el beneficio de exponer a niños pequeños a tecnologías de comunicación e información. El presente estudio descriptivo demostró cómo un curso de educación a docentes antes de la práctica en educación preescolar brindó oportunidades a los estudiantes de educación para aprender y enseñar en línea. Este estudio muestra las experiencias y reflexiones de un profesor académico en un curso de práctica ofrecido en el Semestre de Primavera del 2020 en los Estados Unidos. Describe tres fases de las experiencias en línea de estudiantes de educación: Preparación, Implementación y Reflexión. Los estudiantes de educación informaron sobre las tareas de aprendizaje y enseñanza logradas en cada fase. Las experiencias de enseñanza en línea brindaron a estos maestros en práctica, oportunidades para interactuar con los niños y así mismo motivaron la reflexión sobre la mejor forma de promover el desarrollo y aprendizaje de niños pequeños por medio del uso de herramientas de comunicación en línea.

\section{Introduction}

A teaching practicum provides student teachers with authentic and hands-on experience for teaching in classrooms. In early childhood education, practicums provide student teachers with opportunities to apply their knowledge about children's development as well as about curriculum content. It supports the development of teaching skills to be effective early childhood teachers (Johnson et al. 2017; NAEYC 2009), including dealing with various challenges which influence teaching efficacy in practice (Johnson et al. 2017). A number of teaching practicums are usually required to be completed in course accreditation of early childhood teacher education programs. For example, New York State Education Department requires college-supervised, 
student teaching experiences in different early childhood settings-Pre/Kindergarten, Kindergarten, and primary grades. ${ }^{1}$

In March of 2020, however, most states in the USA had to close all schools due to coronavirus (COVID-19). College classes moved online and remained closed for the rest of the academic year. Student teachers in practicum courses also had to discontinue teaching in schools. As an alternative to student teaching, it was suggested that student teachers should observe videos of early childhood classrooms and present lessons to their colleagues online. As an instructor and supervisor of a practicum course, I considered the possibilities for the student teachers to teach children online. The student teachers would learn more from teaching and interacting directly with children. In a short period of time, I had to redesign and arrange an online teaching schedule so that my students could meet with me as the supervisor and also to teach children online, in order to meet practicum requirements.

This descriptive study discusses how online teaching with my students was completed in the practicum class, while also addressing the following questions:

(1) What should be done at different phases of an online student teaching course for early childhood student teachers to teach children online?

(2) What kinds of support are needed for online student teaching in early childhood education?

(3) What are the limitations and possibilities for online student teaching in practicums for early childhood education?

\section{Online Learning and Distance Education}

Online learning is an educational process which takes place over the Internet. It is a form of distance education to provide learning experiences for students, both children and adults, to access education from remote locations or who, for various reasons, cannot attend a school, vocational college, or university. Distance education addresses issues related to geographical distance but also for many other reasons which prevent in-person attendance at classes (Hrastinski 2008; Moore et al. 2011; Singh and Thurman 2019; Watts 2016; Yilmaz 2019).

Online learning experiences through distance education can be either asynchronous or synchronous (Table 1). Asynchronous learning occurs when students can choose their own time for participation in learning through different media tools such as e-mail or discussion boards. Students can log-into communicate and complete activities at times of their own choosing and learn at their own pace. In contrast, synchronous learning activities occur through live video and/or audio conferencing with immediate feedback (Hrastinski 2008).

\footnotetext{
${ }^{1} \mathrm{http}: / / \mathrm{www}$.nysed.gov/college-university-evaluation/general-and-program-specific-requirements-early -childhood-education
} 
Table 1 Asynchronous and synchronous learning

\begin{tabular}{lll}
\hline & Asynchronous & Synchronous \\
\hline Timing & Log in at own time & Log in at the same time \\
& Learn at own pace & \\
Communicate & Post responses to activities & Face-to-face interactions \\
& Read and write feedback & Talk back/forth within a group \\
Examples of tools & E-mail & Video and/or audio tool (e.g., Google \\
& Discussion board (ex. Google & Hangout, Blackboard Collaborate, Zoom \\
& Doc. Blackboard) & Meeting) \\
Role of teacher & Set up discussion boards & Instructor \\
& Facilitator between students & Interact with students \\
\hline
\end{tabular}

\section{Benefits \& Limitations of Online Learning}

Whether it is asynchronous or synchronous, online learning has several advantages: For instance, it does not depend on being in the same physical location and can thus increase participation rates. In addition, it can be cost-effective because online learning reduces travel and other costs required to attend in-person classes and also may provide learning opportunities for adult students while also engaged in full-time or part-time jobs (Fedynich 2014; Yilmaz 2019). Moreover, online learning can be a convenient means for communication among participants as well as instructors because participants do not have to meet in person.

Limitations of online learning can vary depending on the instructors' or students' technological abilities to access online sites and use computers. These limitations are more evident for young children or school-age students who may not have online access or who have had limited experience with online learning tools, such as computers (Fedynich 2014; Wedenoja 2020). An additional limitation to consider is that young children's online learning, as well as online access, requires adult supervision and, therefore, adult availability and involvement also (Schroeder and Kelley 2010; Youn et al. 2012). Moreover, online learning may not give sufficient or appropriate opportunities to involve young children who need more interactions and hands-on activities to focus and learn compared to adult learners.

The need to take account of children's developmental levels is necessary, as well as to find online learning tools, which are appropriate and which can promote children's participation and learning. Many video communication platforms are convenient tools for children's online learning. Such platforms allow for real-time class meetings and conversations similar to those that take place in face-to-face classes, even though it still does not provide exactly the same social experiences as face-toface interactions. Young children may not have the technology skills necessary for online learning tasks, such as typing responses into a chat screen or sharing files with written information. However, the different functions and tools of many video communication platforms can benefit children's learning when teachers use them appropriately. For example, the 'share screen' function allows participants to present pictures, video clips, or use other visual/audio presentations from a computer. 
Whiteboards can be pulled up by a teacher to draw or write, while at the same time, explaining ideas and interacting with children online.

\section{Children's Online Learning and Teaching in Early Childhood Education}

There are researchers and educators who believe that the use of Information Communications Technology (ICT) in preschool education is necessary and that it can support both the teachers' and children's development. However, others have pointed out that technology can also come with risks and limitations (McPake et al. 2013; Plowman et al. 2011). Despite these controversies, the numbers of young children who are now using online tools is increasing rapidly due to touchscreen technologies and Internet accessibility. ICT in contemporary education offers also potential to provide creative and communicative activities for children. Therefore, it is important to draw educators' attention to these issues about how to provide safe and healthy online environments which are appropriate for children, to develop their thinking skills and understanding of technologies for learning in the 21st century (Edwards et al. 2018; Manches and Plowman 2017; McPake et al. 2013).

The quality of children's online experiences can differ depending on the support provided, as described in a sociocultural framework. Children can learn the benefits from observing a diverse range of technologies. Guided interactions can support children to acquire knowledge and skills, and develop positive dispositions about distance education. How teachers enhance children's encounters with technologies through guided interactions is a key consideration to support children's engagement with online learning (NAEYC 2012; Plowman and McPake 2013; Stephen and Plowman 2008).

Early childhood teachers' efficacy in using technology is another issue in the effectiveness of distance education. The attitudes and skills of early childhood teachers in the use of technology also affect children's motivation and learning. Early childhood teachers often use technologies in their teaching, but usually as teaching tools to show pictures or videos. They need to take on additional roles if they are to teach online (Kalogiannakis 2010). Teachers might find that the use of technology is difficult (Konca et al. 2016; Lindahl and Folkesson 2012; Yurt and Cevher-Kalburan 2011). Early childhood teachers' difficulties in using ICT may come from the gap between e courses they took in their educational programs and the level of ICT now in use that they are expected to use in practice (Kalogiannakis 2010; Wetzel et al. 2004). Therefore, well-designed courses can increase teachers' motivation and their use of new technology (Chen and Chang 2006; Kerry and Farrow 1996).

In teacher education courses, the opportunities to learn how to effectively teach young children through online programs have not been an important consideration. However, because of COVID-19, then it may well mean that much more consideration needs to be given to designing appropriate approaches and practices. The traditional delivery of teacher education programs in classrooms may need to be considered with new ways, new skills and knowledge that early childhood teachers may need in the future in order to teach online. 


\section{Delivering Student Teaching Online}

The following sections describe the different phases of planning, implementation, and reflection in redesigning the process for the practicum for the student teachers. Many problem-solving skills are required for any teacher educators, whether they are teaching online or in face-to-face classes. With no other option but to offer courses online due to recent school closures in the USA as a result of COVID-19, I decided to take a new path and design an online course for the student practicum which I was required to teach in 2020.

\section{Phase 1: Planning}

Learning to teach online When the college took a pause for a week in March of 2020 to move classes to distance education for the rest of the semester, I spent most of that time trying out different online tools, mostly video communication technology such as Zoom, Google hangout, and Blackboard Collaborate. I had used these different technologies in my classes but needed to think about these technologies in new ways to teach online in order to implement new ideas that my students could use when interacting with young children online.

There was no major difference in terms of content knowledge. My main subject area is music education. However, I also added other information about online teaching and distance education to the existing content. Ways to deliver the online content had to be considered. I incorporated both asynchronous and synchronous approaches to teaching. Asynchronous classes were designed for discussion boards so that students could post their reflections on the topic of the week and respond to others' postings. Synchronous sessions were created, as scheduled classes, so that contents could be delivered while we interacted with each other online. A few days before the classes resumed, I sent the students an e-mail with information about the online meetings.

Preparing student teachers for online teaching Immediately after the planning break, the class met using a video communication tool. It took a while until everyone was able to join with enabled audio and video. The first online class began with an introduction to online communication tools. Student teachers got an opportunity to practice different functions of the tools, such as sharing screens from their computers, drawing on a whiteboard, and typing on a chat screen. This first class went better than expected, relieving the students of their concerns and frustrations.

While teaching online, I tried to use various tools: whiteboard for drawing, screen share to present course materials using software programs I had on my computer. My use of online tools gave the students opportunities to reflect on what was efficient and what should be considered by observing my different ways of teaching online. I also tried to make class activities more hands-on. For example, I asked them to bring a household object that could make a sound and download a virtual instrument to be played for an online music session.

While the students became skilled and adapted to new situations, I also needed to recruit child and family participants in order for the student teachers to have 
opportunities to teach children online, in order to fulfill the course requirements for a practicum. Each student teacher needed to have the opportunity to teach young children in, at least, one online class.

I recruited a number of Pre/Kindergarten and Kindergarten children, aged 4 and 5 years, by posting on a Social Networking Service (SNS). I was able to recruit enough number of volunteers from different US states within 2 weeks. After receiving applications, I e-mailed the parents of the children to inform them of what would be done in a virtual class and collected consents to video recording. Subsequently, I had an online interview session with each family to check out their accessibility and usage with the video communication tool. I also had an informal conversation with each individual child to get some ideas about each child's developmental characteristics such as attention level, ability to speak, and so forth. Every conversation with a child was video-recorded and presented to the students in the next online class. Class discussion included what they found out about each individual child from the online interviews and how they could make online teaching effective, motivate children, while taking account of individual differences, and providing appropriate materials.

\section{Phase 2: Implementing}

Communication Based on my trials of online teaching and class discussion, we decided to have four children for each student teacher's online class session so that each student could interact with each child efficiently and also see all the children clearly while sharing the screen in the visual presentation. It was also discussed that each student's online class session would involve their peers, not as participants, but as observers to provide wider experience for each student about how to deliver online teaching by observing each other. This would provide important experiences for students to understand how each person's approach might differ and how different children's participation could also differ, including to assess the nature of children's level of engagement, interest, and learning, and what could be understood about children from these observations.

Good communication was the key to better online teaching. In preparing lessons, student teachers communicated with each other as well as with me. The drafts of their lesson plans were sent by e-mail, and I provided electronic feedback. Virtual office hours also helped when student teachers had questions or materials to show and wanted face-to-face discussion. The students also communicated with each other. For example, one student met her colleague virtually to practice her teaching, checking to see if the sounds or visual materials were appropriately delivered online.

Emails were sent to the parents every week to confirm the date and time of the online class. If needed, parents were asked to gather materials for the online class. For example, parents might ensure that there was a box or a container available for the online class so that children could bang on it to make sounds during the lesson. Handouts were attached to the email so that parents could print information out and be ready for the class, as well as to understand the activities and goals for the online lesson. 
Teaching and supervision Before and after each student's lesson, time was spent in rehearsal and debriefing: Before the online session, time was spent to check that the teaching materials and sounds were working fine and that the student teacher would be able to see all the families when sharing the screen. The video communication tool was set up with a waiting room so that children would wait until they were invited into the 'main room' when the student teacher was ready for the virtual class. Before inviting each child into the 'main room', all the student teachers except the one who would teach muted their video and audio so that children could only see one teacher and the other three children. As the supervisor, I also muted myself except at the beginning of the first teaching day when I introduced the student teacher to the children in the class, because I had already met each child and it was, therefore, respectful to the children to introduce their 'new' teacher.

Each teaching session lasted about $30 \mathrm{~min}$, in consideration of preschool children's attention span. The student teachers taught their lessons using different online tools. However, children didn't use other functions of video communication such as muting/unmuting, chatting, going into break out rooms. While observing, other student teachers could also use the chat function if they needed to communicate with each other.

\section{Phase 3: Reflecting}

Reflection on children's learning At the end of each lesson, the student teacher asked the children what they learned. The children were also asked about their favorite parts of the lesson. This procedure was designed to informally assess children's learning to see what children remembered and how they felt about the lesson. At the same time, it was a signal to indicate the end of the lesson so that parents could help the children to log out. Each lesson was video-recorded and sent to the student teacher after the class so that she could write a self-reflection after reviewing her own teaching.

A debriefing session with the larger class was also carried out after each student's teaching session. Student teachers unmuted and joined together in the main online room. Since they all had observed the same online teaching session, at the same time, students were able to share their reflections on these shared episodes because they had been able to observe the teaching as well as each child's behavior, facial expression, and answers on screen. Each student who had taught shared their reflections of their experience and how it might have been done better. Other student teachers also shared ideas and suggestions for future teaching sessions.

Reflection on distance learning At the end of the semester, the students had opportunities to reflect on their overall experiences of distance education. This was done through two different formats - an online group discussion and an individually written reflection. Student teachers reflected on the benefits and limitations of online teaching and learning, based on their overall experiences. They discussed how they could improve if they were to teach online again in the future. 


\section{Discussion and Implications}

We are living in a rapidly changing world where we need critical thinking, communication, collaboration, and creativity to solve problems and live together. Educators are expected to prepare their students so that they can accommodate any challenges when they face unexpected circumstances (Kim 2017). This year, a 'small' virus brought drastic changes to educational settings. Frustrations emerged from uncertainty about what and how to deal with the circumstances that educators or student teachers had not experienced before. However, whether it is online or in person, teacher educators are required to find appropriate and efficient ways to help develop the skills of their students for problem-solving.

\section{Drawing on the Best of Alternatives}

Unexpected events and circumstances often bring frustration and problem-solving capacities are needed to evaluate alternative courses for actions. Generating alternatives are the means to modify the original plan in the best ways possible, but these ways may also become the better ways of doing things. After the semester was over, a reflection from a student teacher about her experiences included:

"I remember the first Zoom class we had. After that, I did sit down and take breather, cause I was like 'Wow, this is gonna be a long semester, long learning.' It was just a hard lesson online. But as the weeks passed, we got more familiar with Zoom and other features. I feel a lot more comfortable. And I feel like ways of online learning make you become more creative with your lessons, like the online images teach you in ways you wouldn't have considered if you're in the classroom. So, I think it is very beneficial that we've learned all of this now."

One of the benefits of distance education is that it's not limited by the learner's location (Fedynich 2014). In fact, the children recruited for the online classes were from different states, from New York to California. This implies that distance education can be offered not only for the students who cannot come to educational sites but also to student teachers who need experience to engage children from various backgrounds, and not be bound by their locations.

Online communication is a major advancement for distance education, at this point in time, and the types of information and knowledge that can be conveyed. Student teachers didn't have to travel and wait to meet with me during office hours. They sent lesson plans and got feedback through e-mail in a timely manner. Moreover, when further discussion or conversation was needed, a virtual meeting could be arranged using video communication technology. When they had questions, the student teachers were able to share their visual materials to be reviewed, shown in front of the web camera or using online presentation programs. Online communications with parents were also very efficient because information about the class with attached handouts was delivered electronically 
within a day. It also provided a means to involve the parents in their children's online learning experiences.

Online teaching gave student teachers opportunities to learn not only through their direct teaching experience but also by observing others' teaching. When a student only teaches children in a classroom setting, only the supervisor can observe the lesson and debrief with an individual candidate. However, in an online class, other 'muted' peers were able to observe the class as if they were in a laboratory with one-way mirror. In addition to observation, student teachers were able to learn from each other by giving feedback and sharing ideas during debriefing sessions.

\section{Overcoming Limitations: Supporting Environments for Online Learning}

A limitation of online teaching often comes from teachers' limited experience or skills for using ICT. Teacher preparation programs need to focus more extensively on the development of skills for teaching with technology. As an instructor and supervisor in a teacher education program, it was my role to find ways and provide the environment in which my students could learn and teach online. At the same time, the students had to find effective ways to interact with, and teach children online, just as they would do in a classroom. For example, one reflective comment from a student teacher was:

"For me, it has been difficult to adjust because my technical skills are not well developed yet. Besides that, I had very little exposure to taking classes online. Fortunately, my professor developed a well-designed instructional method. This method made us continue our learning in an effective and productive way. Despite the struggles that I had while teaching the lessons online, I can say that I have learned more than I could ever have imagined. For many of the students this semester might have been the worst of all, but for me, I see it as a semester that took me out of my comfort zone. And when you are out of your comfort zone you can learn and experience imaginable things."

Learning subject content is a major purpose for online teaching (Yildiz and Işman 2016). However, the student teachers in this class experienced feelings of success in learning about the processes of online teaching and this had to do with their confidence in utilizing technology and managing a group of children 'properly' online. Even though it was not included in the original syllabus for this subject, in the modified plan delivered to students, they had opportunities to learn about the different communication tools that they could use when teaching online.

While minimizing the limitations of not being able to meet in classrooms, we tried to maximize the benefits of online teaching and learning. Student teachers still need to develop their presentation skills though the online tools, as these skills are somewhat different from those needed to teach in a classroom. For example, student teachers presented visual materials on the screen more attractively through drawing on the whiteboard or showing picture stories on a PowerPoint. Whether a class is offered online or offline, the skills to be a good teacher remain the same. It involves 
interacting with children, building rapport, keeping their attention, encouraging, listening and questioning.

My original ideas to supervise my students online brought up a series of questions, including if it could be done efficiently. The approach presented in this paper made it possible to fill a gap so that students' uncertainties about teaching online could be minimized. For example, student teachers were able to observe children online through watching my informal interviews with children. This helped the student teachers with their planning and preparation of their activities for the children. It also was not easy to provide hands-on activities because children could not touch the materials that the student teachers were showing online. Still, the student teachers always added activities for the children such as drawing, making things, or singing, to their lessons. Overall, the children showed a high degree of concentration in the tasks presented and always mentioned the hands-on activities as their favorite part of the lessons. Parents' support was crucial for distance education not only because children needed help with technology but also the student teachers needed parents' help in preparing materials in order to include more hands-on activities within the lessons. I also needed to stay in close contact with the parents so that I could ask for their help, in preparing materials or printing out a worksheet each week.

\section{Future Delivery of Online Classes with Young Children}

It was an unusual semester and there were trials and errors in the process of transitioning the practicum course to online delivery. If we cannot go back to where we were before COVID-19, our current situation may become a new normal, we should find new ways to improve distance education and online learning and its applications to early childhood education.

The ratio between a teacher and the number of children will be critical in distance education. Synchronous online teaching limits the number of children for several reasons: (a) only one person can speak because an audio communication tool allows us to hear participants' voices only one at a time; (b) a teacher can view only a limited number of children when sharing a screen to present visual materials; (c) young children cannot be separated online for group work or 'turn and talk' because they cannot control the online features for themselves and a teacher cannot supervise different groups in breakout rooms at the same time. Therefore, synchronous online teaching will work better with a small number of the children so that each child has enough opportunity to share and interact. Online teaching in this study worked very well with four children, aged 4-5 years, but it could also be possible with six to eight children, as long as the teacher can manage the processes to engage this number effectively.

When teaching online, it is be an additional task for student teachers to reflect on children's individual differences, as well as their developmental levels. Once children are logged in, the student teachers need to manage each child's different needs, consider their learning styles, personality, and interests. However, online teaching does limit the number of interactions that are possible with children, so student 
teachers have to maximize the value of their communications and language with each child and build a comfortable social environment to encourage all children's participation. A reflection from a student teacher captures this process:

A child was very shy... but I explained to him that he does not have to participate but just listen if he doesn't want to say anything and I tried to encourage him to participate whenever he was ready to do so. He was able to feel more comfortable by the end of the lesson and was participating more frequently which made me really happy."

Play and hands-on activities are important in young children's learning, but they are not easy to do online. The student teachers tried to include hands-on activities children, such as singing and dancing, cutting from a handout and creating a pattern, drawing pictures about a topic, and making an instrument with recycled materials. There was difficulty in singing together because of the sound delay between the teacher and the children when delivered online. The children still loved the singing and playing, and these activities were their favorite parts of the online classes. It is necessary to think creatively about how to design developmentally appropriate practices in which children can engage in a range of hands-on activities online.

\section{Conclusion}

Children learn best through play and concentrate when they can be active through hands-on activities. We may not be able to go back to teaching and learning in the same ways as we did before COVID-19 or to provide the same types of environments and activities as we can implement in a classroom. Therefore, it is critical to think ahead so that we can plan and consider limitations that we may face in the future. It is necessary to provide student teachers with opportunities and skills for such online teaching, including interacting with children through this medium, and also have students reflect about how best to promote development and learning using online communication tools.

Online teaching requires various tasks to be accomplished in the different phases of planning, implementation, and reflection. Critical thinking, creativity, collaboration, and communication are always required no matter whether the class is taught online or offline. Student teachers' experiences for efficient online teaching and learning can be supported by appropriate instructional strategies in college courses for teacher education, as well as through online collaborations with schools and families.

\section{References}

Chen, J., \& Chang, C. (2006). Using computers in early childhood classrooms: Teachers' attitudes, skills and practices. Journal of Early Childhood Research, 4(2), 169-188. 
Edwards, S., Mantilla, A., Henderson, M., Nolan, A., Skouteris, H., \& Plowman, L. (2018). Teacher practices for building young children's concepts of the internet through play-based learning. Educational Practice and Theory, 40(1), 29-50.

Fedynich, L. V. (2014). Teaching beyond the classroom walls: The pros and cons of cyber learning. Journal of Instructional Pedagogies, 13, 1. https://www.aabri.com/manuscripts/131701.pdf.

Hrastinski, S. (2008). Asynchronous and synchronous e-learning. EDUCAUSE Quarterly, 4. https:// er.educause.edu/articles/2008/11/asynchronous-and-synchronouselearning.

Johnson, A. V., La Paro, J., \& Crosby, D. A. (2017). Early practicum experiences: Preservice early childhood students' perceptions and sense of efficacy. Early Childhood Education Journal, 45, 229-236.

Kalogiannakis, M. (2010). Training with ICT for ICT from the trainer's perspective. A local ICT teacher training experience. Education and Information Technologies, 15(1), 3-17.

Kerry, T., \& Farrow, J. (1996). Changes in initial teacher training: Students' perceptions of the effectiveness of school-based mentoring over time. Educational Studies, 22, 99-110.

Kim, J. (2017). Transforming music education for the next generation: Planting 'Four Cs' through children's song. International Journal of Early Childhood, 49(2), 181-193.

Konca, A. S., Ozel, E., \& Zelyurt, H. (2016). Attitudes of preschool teachers towards using information and communication technologies (ICT). International Journal of Research in Education and Science (IJRES), 2(1), 10-15.

Lindahl, M. G., \& Folkesson, A. M. (2012). ICT in preschool: Friend or foe? The significance of norms in a changing practice. International Journal of Early Years Education, 20(4), 422-436.

Manches, A., \& Plowman, L. (2017). Computing education in children's early years: A call for debate. British Journal of Educational Technology, 48(1), 191-201.

McPake, J., Plowman, L., \& Stephen, C. (2013). Preschool children creating and communicating with digital technologies in the home. British Journal of Educational Technology, 44(3), 421-431.

Moore, J. L., Dickson-Deane, C., \& Galyen, K. (2011). E-Learning, online learning, and distance learning environments: Are they the same? The Internet and Higher Education, 14(2), 129-135.

National Association for the Education of Young Children (NAEYC). (2009). NAEYC standards for early childhood professional preparation, position statement. https://www.naeyc.org/files/naeyc/ file/positions/ProfPrepStandards09.pdf.

National Association for the Education of Young Children (NAEYC). (2012). Technology and Interactive Media as Tools in Early Childhood Programs Serving Children from Birth Through Age 8. Washington DC. https://www.naeyc.org/sites/default/files/globally-shared/downloads/PDFs/ resources/topics/PS_technology_WEB.pdf

Plowman, L., \& McPake, J. (2013). Seven myths about young children and technology. Childhood Education, 89(1), 27-33.

Plowman, L., Stevenson, O., McPake, J., Stephen, C., \& Adey, C. (2011). Parents, preschoolers and learning with technology at home: some implications for policy. Journal of Computer Assisted learning, 27, 361-371.

Schroeder, V. M., \& Kelley, M. L. (2010). Family environment and parent-child relationships as related to executive functioning in children. Early Child Development and Care, 180(1), 1285-1298.

Singh, V., \& Thurman, A. (2019). How many ways can we define online learning? A systematic literature review of definitions of online learning (1988-2018). American Journal of Distance Education, 33(4), 289-306.

Stephen, C., \& Plowman, L. (2008). Enhancing learning with information and communication technologies in pre-school. Early Child Development and Care, 178(6), 637-654.

Watts, L. (2016). Synchronous and asynchronous communication in distance learning: A review of the literature. Quarterly Review of Distance Education, 17(1), 23-32.

Wedenoja, L. (2020). What to expect when you weren't expecting online classes. Rockefeller Institute of Government. https://rockinst.org/blog/what-to-expect-when-you-werent-expecting-online-classes/

Wetzel, K., Wilhelm, L., \& Williams, M. K. (2004). The introductory technology course: A tool for technology integration. Contemporary Issues in Technology and Teacher Education, 3, 453-465.

Yildiz, E. P., \& Işman, A. (2016). Quality content in distance education. Universal Journal of Educational Research, 4(12), 2857-2862.

Yilmaz, A. B. (2019). Distance and face-to-face students' perceptions towards distance education: A comparative metaphorical study. Turkish Online Journal of Distance Education-TOJDE, 20(1), 1302-6488. https://files.eric.ed.gov/fulltext/EJ1201959.pdf. 
Youn, M. H., Leon, J., \& Lee, K. J. (2012). The influence of maternal employment on children's learning growth and the role of parental involvement. Early Childhood Development and Care, 182(9), $1227-1246$.

Yurt, Ö., \& Cevher-Kalburan, N. (2011). Early childhood teachers' thoughts and practices about the use of computers in early childhood education. Procedia Computer Science, 3, 1562-1570.

Publisher's Note Springer Nature remains neutral with regard to jurisdictional claims in published maps and institutional affiliations. 